\title{
What do upper secondary school teachers want to know from research on the use of ICT and how does this inform a research design?
}

\author{
Anders D. Olofsson ${ }^{1}$ (D) - J. Ola Lindberg ${ }^{1}$. \\ Göran Fransson ${ }^{2}$
}

Received: 26 October 2016 / Accepted: 16 February 2017 / Published online: 7 March 2017

(C) The Author(s) 2017. This article is published with open access at Springerlink.com

\begin{abstract}
This study investigates what teachers taking part in a longitudinal research project on the use of ICT for teaching and learning in three upper secondary schools in Sweden want to learn more about. At the beginning of the project eighty-four teachers were invited to respond to a questionnaire relating to what teachers wanted to learn more about during their participation in a research project, both for themselves, their colleagues and their students. The questionnaire consisted of Likert-scale and openended questions. Sixty teachers responded, thereby yielding a response rate of $71 \%$. In focus in this paper is a qualitative content analysis of the open-ended questions. The analysis revealed six desired areas of learning: (a) technological aspects, (b) how to use ICT for teaching and learning, (c) the Learning Management System (LMS), (d) safety and plagiarism, (e) best practice and (f) collaboration and professional development. The aspects of knowledge addressed in these themes were analysed and discussed in relation to the TPACK model. A conclusion that can be drawn from the analysis is that the teachers inquired different forms of knowledge and that interpretation of 'technological pedagogical content knowledge' only emerged in one of the themes. This study then informed the research design in multiple ways, the two most apparent being a survey of students acknowledging teachers' expressed research interests and the design and implementation of a formative intervention group interview.
\end{abstract}

Anders D. Olofsson

anders.d.olofsson@umu.se

J. Ola Lindberg

ola.j.lindberg@umu.se

Göran Fransson

goran.fransson@hig.se

1 Department of Education, Umeå University, Umeå, Sweden

2 Faculty of Education and Business Studies, University of Gävle, Gävle, Sweden 
Keywords ICT $\cdot$ Research design - Teacher professional development - TPACK · Upper secondary school

\section{Introduction}

In research on the use of information and communication technology (ICT) in K-12 schools, several studies have been conducted on teachers' opinions, experiences, actions or practices from the researchers' own perspectives or interest in specific questions, issues or challenges. As developed below, research on ICT for teaching and learning is criticised for its lack of practical impact (Davis et al. 2013; Säljö 2010). In responding to such critique, this paper addresses what researchers need to know in order to design research projects that will enable teachers to feel that their participation is valuable, satisfying and inspiring and will give them important insights into the use of ICT for teaching and learning. Beginning with what teachers describe as central aspects of their teaching and learning, and what they want to learn more about from research, this study aims to develop a project design that turns research results into contextual professional development activities that make a positive contribution to teachers' use of ICT for teaching and learning. The paper stems from a fouryear (2015-2018), multi-level and longitudinal research project on the use of ICT for teaching and learning in Swedish upper secondary education.

As a backdrop, the next section discusses what teachers expect from ICT for teaching and learning and presents three reasons as to why research in this area has had little practical impact. The possibilities and challenges of using ICT for teaching and learning that research reports is followed by a brief description of the Technological Pedagogical Content Knowledge (TPACK) model (Mishra and Koehler 2008; Koehler and Mishra 2009) that is used as a part of the analysis. The following sections present the context of the study and the method used for data collection, the thematically ordered result of the content analysis and the discussion, the conclusions and notes about the circumstances under which teachers participate in research.

\section{Background}

At both an international (OECD 2001, 2015) and national Swedish level (Government Inquiry 2014:13; Delegation for ICT in Schools 1999), policy discussions about the use of ICT in K-12 schools have been ongoing. Policies often emphasise the potential of ICT to reform or transform teaching and learning (Håkansson Lindqvist 2015a; Wastiau et al. 2013), or as Hammond (2014) puts it:

...policy and practice in the use of technology have been "distorted." In particular, the use of ICT has been unquestioned, policy has focused on adoption rather than pedagogy, and beliefs about ICT are characterised by determinism, for example, a belief that children will find the use of computers inherently interesting or introducing ICT will necessarily lead to curriculum reform (p. 194). 
Given that the rhetoric about ICT in schools is mostly positive, it can be noted that in more recent publications expectations seem to have been overrated (OECD 2015). Starting in 2009, STELLAR (the European Network of Excellence contracted by the European Commission to support future policies for ICT in European education) aimed to structure the research field of technology enhanced learning (TEL). In 2014, STELLAR presented educational visions for Europe 2020, the EU's strategy for a smart, sustainable and inclusive economy (Fischer et al. 2014). One of the key visions is to construct multi-level evaluations of the use of ICT in European K-12 schools in order to inform educational practice through educational research (Olofsson et al. 2014). In a review of research, Olofsson et al. (2015) argue that the use of ICT in K-12 school for teaching and learning is a complex process that needs to be understood in both theory and practice. Further conclusions in the review are that several perspectives are needed to understand ICT. The review recommends educational research on ICT to go beyond minor case studies of successful implementation activities and instead conduct larger longitudinal studies that consider the potential or difficulties of using ICT for teaching and learning in multifaceted K-12 educational environments. This recommendation seems to be a guiding principle in the research project 'Making a digital difference? An investigation of new technologies in secondary schools' led by Professor Neil Selwyn, which focuses on the 'state of the actual' rather than the 'state of the art' of educational technology in Australian secondary schools (Bulfin et al. 2016).

The aim of this paper is to expand on these recommendations in the context of a four-year research project on ICT in teaching and learning in three Swedish upper secondary schools. The project involves students, teachers, and school leaders. It also involves personnel at municipality level who are involved in the development of local strategies and planning. However, this paper focuses on the teachers in the three schools. It reports on the first round of data collection in the project using a webbased questionnaire responded to by the teachers at the schools; the aim of the questionnaire being to capture the contextual information needed to design forthcoming research- and development activities in the project that are most relevant for the teachers' use of ICT for teaching and learning. In order to make full use of the teachers' comments in the questionnaire, this paper: (a) presents a content analysis of the data and identifies empirically based themes, (b) presents an analysis of the themes using the lens of the TPACK model (Mishra and Koehler 2008) and (c) relates and discusses the outcome of recent research in this field. Prior to that, the next section outlines some of the research-based reasons as to why the use of ICT in K-12 schools have not yet had the expected impact.

\section{ICT in school - notes from a research perspective}

The use of ICT for teaching and learning in K-12 schools has not had the practical impact that was both expected and hoped for. However, it could be that these expectations and hopes are unrealistic considering the complexity and multidimensionality of educational contexts. For instance, the logic of policy as organising, structuring and providing directions for the future may be too general and decontextualised to be applicable in many contexts (Ball et al. 2012). From this perspective, the non-fulfilment 
of expectations could be due to extensive visionary and future-oriented ideas rather than shortcomings in the uptake and use of ICT. However, the three themes of reasons outlined below present additional arguments that are found in research.

\subsection{Reason 1: Critique of the research conducted in the field}

Research that criticises the use of ICT for teaching and learning tends to search for results that are general rather than specific and contextual (Lindberg et al. 2017; Hayes 2006). Over time, research has found it difficult to describe the extent to which ICT affects the structure and culture of schools (Davis et al. 2013; Gu et al. 2013; LeBaron and McDonough 2009; Papert 1997). Further, using arguments from Ertmer et al. (2012) and Schrum and Levin (2013), there is a need for research on K-12 schools that are known for their successful uptake and use of ICT for teaching and learning. Säljö (2010) claims that results from the use of ICT in school are seldom successful at a general or subject-specific level. Hayes (2007) identifies the need for additional and reliable knowledge about how ICT enhances teaching and learning. Other critical voices in research relate to the lack of up-to-date and research-based strategies for the up-take and use of ICT for teaching and learning in upper secondary schools (Håkansson Lindqvist 2015a) and the need for a design perspective on teaching and learning in research on ICT in K-12 schools (Hauge 2014). Some researchers claim that there is very little evidence to suggest that the use of ICT in school develops the pedagogy or has a positive effect on students' learning experiences (cf. Beckman et al. 2014; Ertmer et al. 2012; Hew and Cheung 2013; Hodges and Prater 2014; McGarr 2009; Voogt et al. 2011). Tondeur et al. (2009) argue that in order to understand the use of ICT for teaching and learning, research studies should also include in their design the structural and cultural factors at the different levels of the school as an organisation. They maintain that:

...structural characteristics can also influence cultural characteristics. If, for instance, more innovativeness in schools is desirable but the infrastructure doesn't allow teachers to use new technologies, this will act as a barrier. This calls for research about the causal nature of the relationships discussed (p. 232).

\subsection{Reason 2: The challenged teacher}

Research literature on the role of the teacher in K-12 ICT classrooms describes that teachers have to address a variety of challenges in their daily use of ICT in teaching and learning (Sipilä 2014). For instance, Sipilä suggests that teachers' own digital competence is closely connected to the regular use of ICT in teaching and learning in schools (see also Krumsvik 2008). Related to the question of digital competence, Howard (2013) discusses teachers' perceived risks of using ICT for teaching and learning. Teachers are not necessarily resistant to the use of ICT, but are often worried about how their identity as a teacher might change as a result of using technology in the classroom. Ward and Parr (2010) note that two important factors for the use of ICT in school are that teachers experience a personal need for it and feel digitally competent enough to manage it. In turn, Wang et al. (2014) claim that ICT is often integrated in a teacher- 
centred way in the classroom, and thereby also (as they call it) in a passive way. ICT does not imply that something new occurs in the pedagogical situation. Rather, ICT is a tool that students use in the classroom in similar ways as other tools that the teachers provide (see Livingstone (2012) for a similar conclusion). Related to these results, Albion et al. (2015) report that one way of changing classrooms practices is to work with the teachers' beliefs about ICT for teaching and learning. According to Vrasidas (2015), national governmental directives that require teachers to use ICT is challenging. Vrasidas writes that:

...mandating the use of technology by teachers is not the best way to integrate technology in teaching and learning. A better approach is to prepare teachers, to improve their competencies in ways that teachers can appreciate the value of technology and how it can help their students learn (p. 372).

\subsection{Reason 3: The question of teachers' professional development}

The third reason concerns teachers' professional development (TPD). For the use of ICT in teaching and learning to be sustainable, it needs to be supported by TPD (Lindberg and Olofsson 2010). However, planning for and carrying out TPD and allowing for its practical impact in the classroom can be challenging (See et al. 2016; Tondeur et al. 2016). For example, teachers' subjectivity largely influences the outcome of TPD (Fore et al. 2015). Another example, using Håkansson Lindqvist's (2015b) arguments, is that time for and access to ICT-related TPD, combined with limited possibilities for teacher collaboration in schools to develop local digital teaching practices, are factors that influence how teachers use ICT for teaching and learning in upper secondary school. Penuel et al. (2015) offer a third example:

Researchers often imagine that the best way to bridge that gap is to translate basic research on learning into interventions that are feasible for teachers to implement, effective for a wide range of students, and accessible to any student who might benefit from them (p. 182).

Phelps et al. (2011) report that TPD in the use of ICT for teaching and learning is becoming more popular and important, although at the same time is in constant need of renewal. In addition, transferring any new skills and ideas that teachers develop through TPD into their classrooms is difficult.

\subsection{Turning the research-based reasons into practice}

According to the first reason and the critique of the research that has hitherto been conducted, future research using new designs to investigate the uptake and use of ICT for teaching and learning in K-12 schools is both requested and necessary. TPD needs to acknowledge, address and integrate the lessons learned from reason two about the challenges that teachers face. Following reason three, there is a call for teachers' strengthened influence and agency in professional development and research. This paper reports on a study within a four-year research project on ICT in Swedish upper 
secondary schools. The three research-based reasons above have informed the design of the project. The next section presents a way of understanding teachers' knowledge about how to use ICT for teaching and learning. Later in the paper this serves as a lens through which to understand the different forms of knowledge the teachers express.

\section{The TPACK model}

The TPACK model is often described and understood as a development of Shulman's (1986, 1987) ideas about pedagogical content knowledge (PCK). Shulman developed a model that facilitates the study and understanding of the relationship between teachers' pedagogical knowledge (PK) and content knowledge (CK). Based on Shulman's thinking, Mishra and Koehler (2008) consider that nowadays teachers also need an extended technological knowledge (TK) in order to plan and conduct their teaching. This assumption is the point of departure for their extension of Shulman's PCK into a model for studying and understanding teachers' so-called technological content knowledge (TCK), technological pedagogical knowledge (TPK) and technological pedagogical content knowledge (TPACK). In short, put together and integrated, PCK, TCK and TPK constitute TPACK. In the words of Mishra and Koehler (2008), TK includes "the skills required to operate particular technologies" (p.4). CK concerns "knowledge about the actual subject matter that is to be learned or taught" (p.4) and PK is "deep knowledge about the processes and practices or methods of teaching and learning and how it encompasses (among other things) overall educational purposes, values and aims" (p.6). TCK is an "understanding of the manner in which technology and content influence and constrain one another" (p. 7), whereas TPK is "an understanding of how teaching and learning changes when particular technologies are used" (p. 9). In turn, PCK concerns how "teachers interpret subject matter, find multiple ways to represent it, and adapt instructional materials to alternative conceptions and students' prior knowledge" (p.9). Finally, Mishra and Koehler regard TPACK as "the intersection of all three bodies of knowledge. Understanding of this knowledge is above and beyond understanding technology, content, or pedagogy in isolation, but rather as an emergent form that understands how these forms of knowledge interact with each other" (p. 10). The model in Fig. 1 shows how the different forms of knowledge overlap and that TPACK is the model's hotspot.

The TPACK model has its scope and limits and its use and usefulness has been discussed in several research reviews (cf. Voogt et al. 2013; Yeh et al. 2014). A conclusion that can be drawn from these reviews is that the model can be used and understood in different ways. It has been seen as a tool to better understand the forms of knowledge that teachers are required to have in teaching with technology, and as such is of a conceptual nature (Cox and Graham 2009; Graham et al. 2012). The model can examine different forms of teaching and learning designs intended to promote or develop teachers' knowledge, skills, and competencies in teaching with technology, for instance in teacher education (Polly et al. 2010). The TPACK model serves two purposes in this paper. The first is to analyse and discuss the themes that emerge in the content analysis of the questionnaire data. This is done by identifying central aspects of the teachers' teaching and what they would like the research in the project to focus on and comparing the research results with what has already been concluded in former 


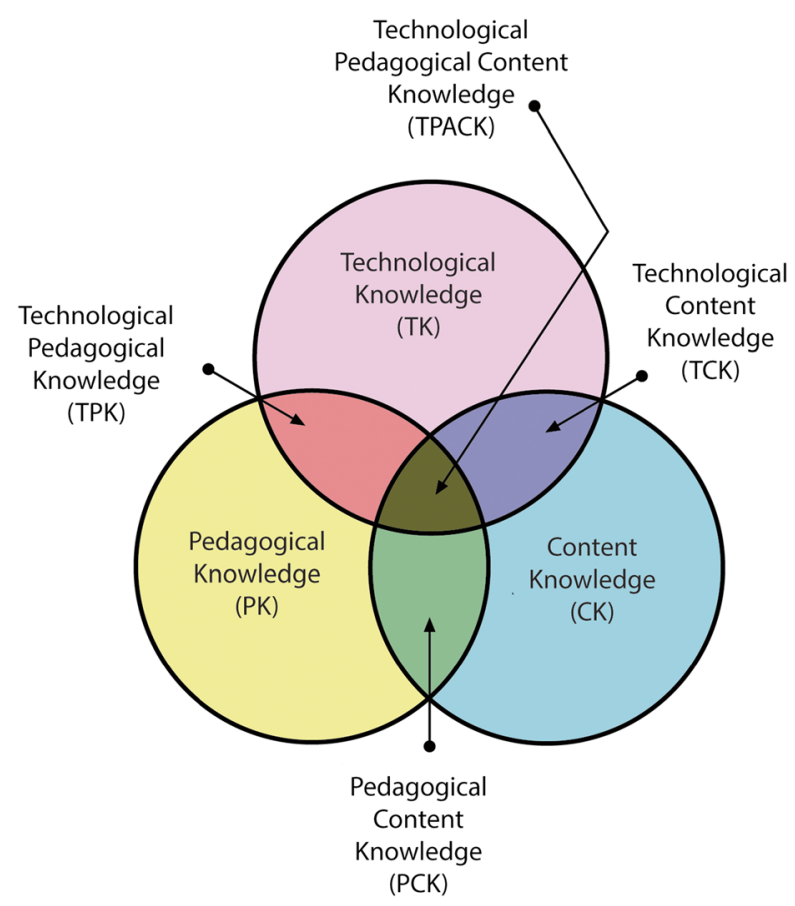

Fig. 1 TPACK model after Mishra and Koehler (2008)

research. The aims here are twofold, namely: (a) to create a feeling of power among the teachers participating in the project and that the project is experienced as an important part of their professional development and (b) to influence new research that will provide new knowledge about the potential use of ICT in education in Sweden and globally. The second purpose is its use as a framework for the research project to design and try different forms of formative interventions with the aim of developing the teachers' use of technology in their own teaching and learning and in their students' learning.

\section{Context}

The context of this paper is the above-mentioned research project. Three Swedish upper secondary schools take part in the project. The participating schools are 'known' for their advanced use of ICT in teaching and learning. However, advanced use is something that has been projected onto the schools. First, all three schools were early adopters of a one-to-one school system, which means that every student and teacher has their own computer. Second, it is possible to trace the advanced use to different specific contextual circumstances: for school A to the national reputation of the municipality regarding the use of ICT in its K-12 schools, for school B to a specific centre of technology at the school sponsored by a private founder, and for school $\mathrm{C}$ for its expertise in the area of remote teaching. Thus, the use of ICT differs somewhat from school to school. A description of the schools are: School A is located in a municipality 
that has profiled itself as using ICT to support teaching and learning. Since the mid1990s, strategic efforts have been made to improve the ICT infrastructure, and teachers and school leaders have been enrolled in professional development activities in order to make better use of these tools; something that the municipality has won much acclaim for. School B is located in one of Sweden's largest municipalities. In recent years, the municipality has worked hard to integrate and make use of ICT in its upper secondary schools. Due to School B's advanced use of ICT, a private foundation made it possible to establish a Centre of Technology and to administrate 1,070,000 Euro over a period of 10 years for student scholarships. School C is located in a rural part of Sweden. It is the only upper secondary school in the municipality and has about 120 students and approximately 20 teachers. The school has a reputation for its remote teaching and learning format, as well as its well-established international partnerships. One of the school's former leaders recently received a nationally recognised award for his extended work in integrating ICT and media at the school.

The research project has a double intention, both to investigate the uptake and use of ICT in the participating schools and to drive school development and change on these conditions. Collaboration with the teachers means that it is possible to inform the design of the research project, including both the setting up and carrying out of evidence-based TPD activities. Activities like this are more likely to contribute to teachers developing a more reflected understanding of the uptake and use of ICT for teaching and learning in upper secondary school.

\section{Method}

In spring 2015 the teachers at the three upper secondary schools were invited to answer a web-based questionnaire. The ambition with this was to design a bottom-up approach for a longitudinal and multilevel research project foregrounding involvement and collaboration. With the intention of including as much variation as possible, teachers from the natural science programme, the technical science programme and the vocational programme for electricians were asked to participate. The project has a whole school approach, although for practical reasons there is a specific focus on the teachers from these three programmes. This sample may lead to some bias in the results compared to involving every subject teacher in the school. On the plus side, the participating teachers from these programmes represent a number of subjects related to the fields of science, social science and humanities and as such represent subjects with different rationales and cultures for ICT use (cf. Karaseva et al. 2013; Tay et al. 2015). Further, the extent to which they use ICT varies and many of the teachers teach in other programmes in the schools. The teachers all taught Years $1-3$ in the different programmes.

In total, 60 of 84 possible teachers responded to the questionnaire, giving a response rate of $71.4 \%$. In addition to questions about their previous experience of using ICT and what they expected from the project, the questionnaire also included questions about the three schools. The questionnaire consisted of 10 questions with a mixture of background questions with fixed alternatives, questions requiring Likert-scale answers in combination with optional text comment boxes and questions with open comment boxes only. The main questions analysed for this paper are: "Regarding ICT in upper secondary school, state what you personally would like to know more about - for the 
sake of the students, for the sake of your colleagues and for your own sake." The teachers also related to statements on a Likert scale. For example: "Based on your experiences of teaching, what do you think about the following statements: "The use of ICT in upper secondary school: increases students' motivation for their school work' and 'ICT is an important tool in my teaching'". A content analysis (Bulfin et al. 2016; Miles et al. 2014) of the open-ended qualitative questions was conducted using the NVivo software.

The reasons for using different kinds of questions and statements in the questionnaire are to collect background data about the schools, to map how the teachers conceptualise the challenges and possibilities of using ICT in their teaching practices and to determine how they rate ICT as a facilitating tool in their students' learning. The relatively rich use of optional text comment boxes and the open-ended qualitative questions are also an attempt to capture the teachers' descriptions of their own personal interests in and experience of using ICT in teaching and learning. In the project, this information is the starting point for formulating questions of personal importance for the teachers. The information is also used to suggest research-based changes in the schools and joint teacher activities related to ICT in teaching and learning. The aim of this bottom-up approach is to make a difference in the schools without being yet another TPD activity with little transferability into teachers' classrooms (Phelps et al. 2011). The next section presents the results of the questionnaire in terms of basic descriptions and identified themes.

\section{Results}

First, this section provides a background description of the participating teachers and introduces the six themes that emerged during the content analysis in NVivo. The themes are analysed through the lens of the TPACK model. The quotations serve the purpose of illustrating the different kinds of knowledge interpreted in the themes.

\subsection{Who are the participating teachers?}

In total $37 \%$ of the respondents have worked at the upper secondary school level for more than 10 years and $25 \%$ have worked at that level for over 20 years. When rating their present level of competence in using ICT for teaching in class, $62.7 \%$ of the respondents chose the alternative "relatively competent to handle ICT for that purpose" (mean value of 2.1 on the Likert scale 1-4). The teachers also related to a number of statements about the use of ICT in upper secondary school. From the teachers' responses to the statements, a conclusion is that that most of them regarded ICT as an important tool in their teaching practices. They also reported being relatively comfortable with today's rapid development of various ICT tools in the light of their own current use of ICT. Another aspect was that the teachers' overall opinion was that ICT had the potential to increase their students' motivation for school work.

The content analysis of the questionnaire data shows that the teachers wanted the research project to provide them with new knowledge and TPD activities that relate to the use of ICT in their everyday practices in school. The analysis also resulted in the six themes described below. 


\subsection{Theme 1 - technological aspects}

The first theme concerns "know-how about technological aspects of ICT, such as how to use digital devices or digital educational software". Many teachers wanted to learn more about using different kinds of digital devices, such as a more advanced use of laptops, smartphones and tablets. Some of the teachers wanted to learn more about computing. One teacher expressed that: "I would like to gain more knowledge about app-programing, at present I do some web exercises and demonstrations, mostly in Java and PHP, but I would very much like to do this in an app-format, because I think that the students would benefit from it" (interpreted as TK). The most common answers were a desire to learn more general or basic ICT skills. Examples given in the questionnaire were: "Improve my skills when it comes to putting together or linking to different kinds of files" (interpreted as TK) and "To deal with existing tools like Excel/ search engines/social media" (interpreted as TK).

Through the lens of the TPACK model, the analysis of theme 1 shows that according to the teachers at all three schools, technological knowledge (TK) is a highly relevant form of knowledge for the project to focus on. Further, that there is a lot of variation in the teachers' answers about the complexity and level of TK requested.

\subsection{Theme 2 - how to use ICT for teaching and learning}

In the second theme the teachers address different aspects of "know-how about using ICT-tools and applications for teaching and student learning". New knowledge is requested about how ICT tools could support them in their teaching practices, such as "Educational programs like Kahoot, different PowerPoint programs" (interpreted as TK) or "Tools to use when constructing functional, anonymous and rapid questionnaires. Both for Android and the computer" (interpreted as TK). Many of the teachers expressed the need to learn more about how to use the smartboard in an effective way. Other suggestions included the use of "Anonymous log books on the net which I as a teacher can use in collaboration with the students" (interpreted as TPK), or that "It was interesting to try flipped classroom and find out whether that activity could support certain groups of students" (interpreted as TPACK). Some of the teachers wanted the project to provide them with knowledge about how ICT could help to motivate their students in school: "To in an uncomplicated way make the students more involved through ICT" (interpreted as TPK) or "...how ICT could attract students to study in-depth" (interpreted as TPK).

Through the lens of the TPACK model, the analysis of theme 2 shows a more diverse picture, in that the teachers express the need for technological knowledge (TK), technological pedagogical knowledge (TPK) and to some extent technological pedagogical content knowledge (TPACK). In this theme, the expectation was that the teachers would emphasise TPK and TPACK as the most important forms of knowledge for the project to focus on. However, amongst the teachers, there seems to be a need to manage the technology for digital educational programs or applications before using them in the classroom. 


\subsection{Theme 3 - the learning management system (LMS)}

The third theme concerns "know-how that improves the use of the schools' Learning Management System (LMS)". All three schools use LMS as a web-based platform for teaching, learning and administration. This theme shows that the teachers want the research project to contribute more advanced knowledge about the functionality of LMS in order to support themselves, their colleagues and their students. Recently, a new LMS had been introduced at two of the schools. Here, requests from the teachers ranged from "First of all I need to learn how to use the LMS" (interpreted as TK) to those wanting to learn more about the LMS “...in order to be able to help my colleagues" (interpreted as $\mathrm{TK})$. The responses also pointed to the need for more specific operational knowledge, such as "How to document in an easy way, which is a good LMS compatible with different kind of smartphones (Android and iPhone)" (interpreted as TK). Other requests included the possibility for LMS to mediate access and contact between teachers and students: "If you save lectures and similar on the students' LMS, who loses or gains from it? How should we think in order to reach all the students?" (interpreted as TK). Further that the project should provide knowledge about LMS as a learning tool, such as how "To create digital tests in our new LMS" (interpreted as TPK).

According to theme 3, LMS appears to be an important digital hub in all three schools. The analysis shows that apart from some of the requests for technological pedagogical knowledge (TPK), the dominant form of knowledge in this theme is technology knowledge (TK). LMS has several administrational functions that the teachers need to learn before they can use it for more pedagogical issues.

\subsection{Theme 4 - safety and plagiarism}

The fourth theme focuses on "issues concerning safety and plagiarism". This theme represents the responses to the questionnaire about students not always being careful enough when clicking on web-links or downloading new programs on their laptops. As there is a risk for virus attacks in such situations, it is important that the project also includes activities that "...upgrade the students' knowledge about IT security" (interpreted as TK), as one teacher phrased it. The teachers utilised online services to determine whether their students used non-sanctioned ways when writing assignments in English. As one teacher put it, "I check the students' assignments for plagiarism through URKUND [a net-based company that specialises in detecting and checking for plagiarism]" (interpreted as TCK).

The most common forms of knowledge in theme 4 are technological knowledge (TK) and technological content knowledge (TCK); the former being directed towards the students' knowledge about using ICT safely and the latter towards ICT for subjectrelated matters. The teachers thus appear to regard safety and plagiarism as important issues to address.

\subsection{Theme 5 - best practice}

The fifth theme concerns "examples of best practice in using ICT". Here, the majority of teachers want the project to provide them with different examples of best practice, including methods for using ICT in the classroom. Two characteristic answers are 
"Teaching tips that involve ICT" (interpreted as TPK) and "... when best to use ICT in my classes" (interpreted as TPK). Some teachers asked for help in using ICT to support their students, increase student motivation and interest and support improved study results "How the use of ICT in teaching could improve practice combined with [increasing] the students' interests and results" (interpreted as TPK) or "How do students want me to use ICT in order to facilitate their knowledge construction and development?" (interpreted as TPK). Several teachers had problems with students using ICT in unintended ways during class: "How can I as a teacher make students use the computer for optimal knowledge construction without wandering along unwanted paths such as YouTube?" (interpreted as TPK). Teachers working with students in different geographical locations expressed the need to deepen their knowledge about distance teaching, and related learning practices and wanted to know more about how "To use distance tools in order to make the practice even more flexible?" (interpreted as TPK) or suggestions about "Smart solutions that I am not yet aware of" (interpreted as TPK).

Through the lens of the TPACK model, the analysis of theme 5 shows that the teachers want the project to provide them with new knowledge about the best ways of using ICT for teaching and learning purposes, which can be understood as TPK. However, it is also reasonable to suppose that skills regarded as TPACK are in the background, albeit not explicitly stressed but implicitly possible to derive. However, the teachers do not explicitly address TPACK as such, which means that this fifth theme only addresses TPK. To us as researchers, this indicates that future TPD based on research and carried out in the schools should contain hands-on ICT activities for teaching and learning purposes and collegial dialogues where the connection between ICT and pedagogy is in focus.

\subsection{Theme 6 - collaboration and professional development}

The sixth and final theme revolves around issues of "teacher collaboration and teacher professional development". In this theme, the importance of teachers inspiring each other to use ICT in order to become more knowledgeable about online collaboration is central. Examples of this include student cases and the sharing of teaching and learning materials. The teachers expressed this as "joint understanding about the [ICT] teaching practice" (interpreted as TPK), "how can IT make teacher collaboration easier?" (interpreted as TPK), "how do we introduce ICT for first year students, joint approaches and collaboration?" (interpreted as TPK) and "collaboration by means of the Cloud" (interpreted as TPK). Here, the teachers talked about the possibility of sharing ICT-supported teaching experiences by means of teacher community learning; an activity that could pave the way for a joint understanding of different teaching practices. In addition, in their answers the teachers described the project as a possible basis for increased teacher collaboration. More specific issues were also addressed, such as a reduced workload and the need to access their colleagues' teaching- and learning materials. Many of the responses related to issues about sharing through ICT, such as wanting the project to offer smart ICT solutions so that when "...one has created the material several others can easily use it too" (interpreted as TK). To some teachers this seemed to be a question of a joint or democratic rationale at the school, so that "...all of us should have equal possibilities to access the teaching materials" 
(interpreted as TK). Some of the teachers turned this into a question of ICT per se and how for example "Smooth [online] map solutions could create shared access to teaching materials" (interpreted as TK). Some teachers asked, "What opportunities are there when it comes to teacher community learning through sharing experiences? Some of this is already done today, but not "just" as a certain number of shared documents, what I am looking for is real results with added value" (interpreted as TPK). According to some teachers there were already examples of both collegial learning in the schools and sharing about how to use ICT in practice. One teacher wrote "In my subject teams we are good at sharing information and tips with each other. Even if this is about minor things, it is a kind of continuous professional development. I for example give tips about how to use Kahoot" (interpreted as TCK).

When analysing theme 6 from the TPACK model, highlighted issues are in relation to teacher collaboration and professional activities. This theme shows a need for collegial activities at the three schools and that technological knowledge (TK), technological pedagogical knowledge (TPK) and technological content knowledge (TCK) are all evident.

\section{Discussion}

The content analysis of the data reveals six different themes that teachers want to know more about: (1) technological aspects, (2) how to use ICT for teaching and learning, (3) the Learning Management System (LMS), (4) safety and plagiarism, (5) best practice and (6) collaboration and professional development. Taken together, the themes express important personal views held by the teachers and context sensitive information about the schools. Figure 2 shows the overall analysis of the themes. The most frequent

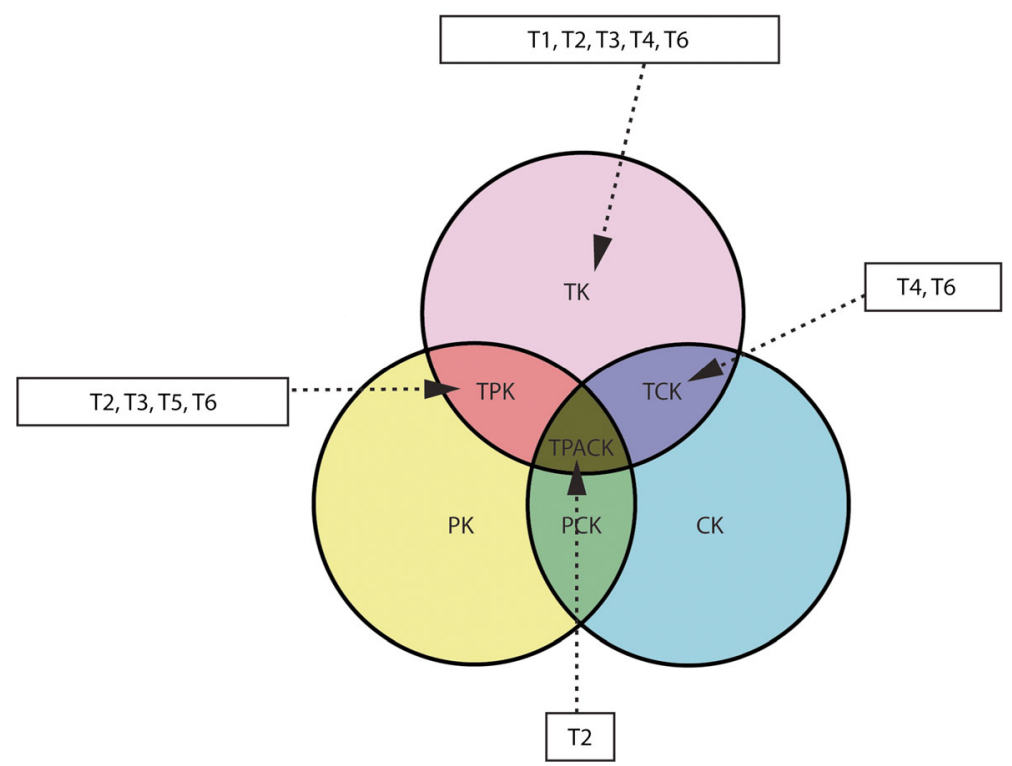

Fig. 2 Analysis of all the themes through the lens of the TPACK model (Mishra and Koehler 2008) 
request from the teachers is the importance of including rich aspects of technological knowledge (TK) and technological pedagogical knowledge (TPK) in the project. They also think that technological content knowledge (TCK) and technological pedagogical content knowledge (TPACK) could receive less attention and pedagogical knowledge (PK), content knowledge (CK) or pedagogical content knowledge (PCK) little attention. However, in the long term, only responding to teachers' current needs, experiences and practices may be short-sighted. It is therefore important to not downplay discussions about TPACK, but instead use this as a starting point for discussions about how technology, pedagogy and content intertwine. Notably, the analysis only shows one major difference between the teachers in the three schools. In school $\mathrm{C}$, some of the teachers highlighted issues related to "remote teaching", which is not surprising given that the school organises the teaching in this way in some subjects.

The themes indicate the forms of knowledge that the teachers would like to acquire, as well as vital forms of knowledge with which they are not yet familiar. Analysing each theme through the lens of the TPACK model clearly shows that technological knowledge (TK) is the most frequent among the teachers and that this is present in all but one of the six themes. This suggests that even when teachers regard themselves as relatively digital competent (cf. Krumsvik 2008), they may still need to acquire "the skills required to operate particular technologies" (Mishra and Koehler 2008, p. 4) and that over the years they have experienced challenges in solving various technological problems concerned with the use of ICT for teaching and learning. It is interesting to note that not only does there seem to be a need to develop more advanced technological knowledge, such as computing know-how, but also more basic knowledge about LMS, including how to use it more effectively and how to use programs like Kahoot or PowerPoint. This indicates the teachers' lack of preparation for the uptake and use of ICT in the classroom and the emergence of new technological applications over time.

How can the teachers' requests to develop their TK be understood? First, as new ICT is constantly being introduced, different upgrades of present digital devices, together with new applications and educational software, have an impact on the ongoing use of ICT in the classroom. A major challenge for the teachers is to keep up with the changes in the use of ICT in teaching and learning; something that requires time, effort and knowledge. Second, as teachers' need to direct their attention towards many different issues, allocating time for involvement in professional development activities related to ICT is a challenge. Third, the lack of technical support at two of the three schools means that teachers are largely left to their own devices when it comes to the technology and software. Fourth, it may be more reasonable to call for the development of TK as it is concrete and practical. Aspects of knowledge, as for instance TPACK, are more elusive and theoretical.

According to the analysis, the second most common form of knowledge is technological pedagogical knowledge (TPK). Many of the teachers' expressions about TPK in this study relate to the hope that the project will provide examples of best practice in using ICT for teaching and learning. The examples given relate to teaching and learning in the classroom, TPD and collaboration with other teachers in the three schools. Expressions of TPK are present in four of the six themes. One interpretation is that 
teachers already have connected an increase in TK with its pedagogical use. Two of the six themes identify TCK, which could be a symptom of a lack of competency in TK, for example if teachers feel that their technological knowledge is insufficiently developed or they find it difficult to make the relevant connections to the use of ICT in their subjects. It could also indicate that teachers seldom experience extensive subjectorientated dialogues in their subject teacher teams at the schools, but instead have to deal with administrative issues related to teaching, learning and assessment or grading. In only one of the themes can the answers be interpreted as relating to technological pedagogical content knowledge (TPACK). As TPACK is a form of knowledge that takes time to develop and master, this is not particularly surprising. However, at the same time, it seems to pinpoint a situation where many teachers have the potential to develop a teaching practice in which pedagogy, technology and content are tightly aligned in a more reflected way.

\subsection{Implications for the research project}

Most of the literature concludes that over the last 20 years the use of ICT in K12 schools has not been extensive or successful (Beckman et al. 2014; Hodges and Prater 2014; McGarr 2009; Säljö 2010; Voogt et al. 2011). In order to drive evidence-based school development and change (Håkansson Lindqvist 2015a), knowledge about what teachers want to know tells researchers what they need to know when designing research on ICT in teaching and learning in school. This is a design that has its starting point in actual situations and departs from teachers' own personal concerns, experiences and knowledge (Ertmer et al. 2012; Penuel et al. 2015; Schrum and Levin 2013).

As can be seen in the study, several kinds of knowledge seem to be central. It is important for the project to target issues that are relevant to the teachers' ICT classrooms and to areas of knowledge that teachers are not very familiar with (Krumsvik 2008; Sipilä 2014). A conclusion here is that the design of the project can contribute to a use of ICT that creates new pedagogical situations, rather than reinforcing old ones (cf. Livingstone 2012; Wang et al. 2014). Finally, we argue that the study outlined in this paper is a first step towards a deeper understanding of the uptake and use of ICT in school and a catalyst for a research-based and contextually valuable TPD for the participating teachers (Penuel et al. 2015).

Researching what teachers want to know from research, this study has explicitly informed the research design in multiple ways. First, a student survey has been designed to highlight the questions that are of interest to the teachers and to us as researchers. Second, a group interview designed as a formative intervention with teachers in a specific subject has been used for both TPD and data collection reasons. The TPACK-model was introduced during the interventions and used as a model to structurally discuss the different aspects of the teachers' teaching practices and competence. Whilst acknowledging the agency of the teachers, this design has provided opportunities for the teachers to reflect and to learn individually and collectively. This design has also rendered deep research data recordings of teachers' reflections, discussions and collaborative sense-making processes. Third, seminars will be organised to give the teachers feedback on the findings and progress of the research project. 


\subsection{Closing remarks}

The design of the research reported in the paper is intended to make the teachers feel that their participation is appreciated and rewarded and that their insights into the uptake and use of ICT for teaching and learning are inspiring to us as researchers. That teachers' involvement can help the research to create an uptake and use of ICT that is sustainable, both during the research and after its completion (cf. Phelps et al. 2011). Given the large body of literature on the major challenges and difficulties of using ICT for teaching and learning, it seems reasonable to expect that researchers design and execute their studies with ambitious goals and their targeted audience in mind. One of the goals in this study has been to critically examine the use of ICT for teaching and learning at the upper secondary school level. Another goal is to provide a reflective and perhaps more complex picture of the possibilities and challenges in the use of ICT in the classroom. Hopefully this paper has accomplished these the goals and contributed to the body of the research in this field. That the research has played a role in local school development in a contextually valuable environment that can endure educational changes is also meaningful (Håkansson Lindqvist 2015a).

Establishing good relations between researchers and teachers requires considerable time and effort. Such an establishment can never be taken for granted. Teachers today are continually under pressure. In terms of using ICT for teaching and learning, they have to constantly manoeuvre between things with conflicting values, their daily tasks and obligations and the demands of students, school leaders, parents and other stakeholders. Thus, finding appropriate times in the academic calendars for involvement in research can be difficult, no matter how significant the project may appear. The study reported in this paper is no exception. It took a relatively long time to launch the project at each of the three schools and to distribute the questionnaire. It also took time to set up a bottom-up approach, which began with a survey of the teachers' knowledge and experience. Without an understanding of the contextual complexity of teachers' everyday practices, it would be easy to blame the teachers for not being interested in ICT for teaching and learning, or in research-based professional development. It is hoped that this research will contribute to the continuous development of the proficiency of using ICT in teaching and serve as a guide for future TPD activities at these three schools.

Open Access This article is distributed under the terms of the Creative Commons Attribution 4.0 International License (http://creativecommons.org/licenses/by/4.0/), which permits unrestricted use, distribution, and reproduction in any medium, provided you give appropriate credit to the original author(s) and the source, provide a link to the Creative Commons license, and indicate if changes were made.

\section{References}

Albion, P. R., Tondeur, J., Forkosh-Baruch, A., \& Peeraer, J. (2015). Teachers' professional development for ICT integration: Towards a reciprocal relationship between research and practice. Education and Information Technologies, 20(4), 655-673.

Ball, S. J., Maguire, M., \& Braun, A. (2012). How schools do policy: Policy enactments in secondary schools. London \& New York: Routledge.

Beckman, K., Bennett, S., \& Lockyer, L. (2014). Understanding students' use and value of technology for learning. Learning, Media \& Technology, 39(3), 346-367. 
Bulfin, S., Johnson, N., Nemorin, S., \& Selwyn, N. (2016). Nagging, noobs and new tricks - Students' perceptions of school as a context for technology us. Educational Studies, 42(3), 1-13.

Cox, S., \& Graham, C. R. (2009). Diagramming TPACK in practice: Using an elaborated model of the TPACK framework to analyze and depict teacher knowledge. TechTrends, 53(5), 60-69.

Davis, N., Eickelmann, B., \& Zaka, P. (2013). Restructuring of educational systems in the digital age from a co-evolutionary perspective. Journal of Computer Assisted Learning, 29(5), 438-450.

Delegation for ICT in Schools (1999). ITiS. En nationell satsning på IT I skolan. [ITiS. A national investment in IT in schools]. Stockholm: Ministry of Education.

Ertmer, P. A., Ottenbreit-Leftwich, A. T., Sadik, O., Sendurur, E., \& Sendurur, P. (2012). Teacher beliefs and technology integration practices: A critical relationship. Computers \& Education, 59(2), 423-435.

Fischer, F., Wild, F., Sutherland, R., \& Zirn, L. (2014). Grand challenges in technology enhanced learning. London: Springer.

Fore, G. A., Feldhaus, C. R., Sorge, B. H., Agarwal, M., \& Varahramyan. (2015). Learning at the nano-level: Accounting for complexity in the internalization of secondary STEM teacher professional development. Teaching and Teacher Education, 51, 101-112.

Government Inquiry (2014:13). En digital agenda i människans tjänst - en ljusnande framtid kan bli vår [A digital agenda that serves the people - a brighter future can be ours]. Stockholm: Fritzes.

Graham, C. R., Borup, J., \& Smith, N. B. (2012). Using TPACK as a framework to understand teacher candidates' technology integration decisions. Journal of Computer Assisted Learning, 28(6), 530-546.

Gu, X., Zhu, Y., \& Guo, X. (2013). Meeting the "digital natives": Understanding the acceptance of technology in classrooms. Educational Technology \& Society, 16(1), 392-402.

Håkansson Lindqvist, M. (2015a). Conditions for technology enhanced learning and educational change, A case study of a 1:1 initiative. Sweden: Unpublished doctoral thesis. Umeå University.

Håkansson Lindqvist, M. (2015b). Gaining and sustaining TEL in a 1:1 laptop initiative: Possibilities and challenges for teachers and students. Computers in the Schools, 32(1), 35-62.

Hammond, M. (2014). Introducing ICT in schools in England: Rationale and consequences. British Journal of Educational Technology, 45(2), 191-201.

Hauge, T.-E. (2014). Uptake and use of technology: Bridging design for teaching and learning. Technology, Pedagogy and Education, 23(3), 311-323.

Hayes, D. (2006). Making all the flashy stuff work: The role of the principal in ICT integration. Cambridge Journal of Education, 36(4), 565-578.

Hayes, D. (2007). ICT and learning: Lessons from Australian classrooms. Computers \& Education, 49(2), 385-395.

Hew, K. F., \& Cheung, W. S. (2013). Use of web 2.0 technologies in K-12 and higher education: The search for evidence-based practice. Educational Research Review, 9, 47-64.

Hodges, C. B., \& Prater, A. H. (2014). Technologies on the horizon: Teachers respond to the horizon report. TechTrends, 58(3), 71-77.

Howard, S. K. (2013). Risk-aversion: Understanding teachers' resistance to technology integration. Technology, Pedagogy and Education, 22(3), 357-372.

Karaseva, A., Pruulmann-Vengerfeldt, P., \& Siibak, A. (2013). Comparison of different subject cultures and pedagogical use of ICTs in Estonian schools. Nordic Journal of Digital Literacy, 8(3), 151-171.

Koehler, M. J., \& Mishra, P. (2009). What is technological pedagogical content knowledge? Contemporary Issues in Technology and Teacher Education, 9(1), 60-70.

Krumsvik, R. (2008). Situated learning and teachers' digital competence. Education and Information Technologies, 13(4), 279-290.

LeBaron, J., \& McDonough, E. (2009). Research report for GeSCI meta-review of ICT in education: phase two. Available online at: https://ia800207.us.archive.org/16/items/ERIC_ED508942/ERIC_ED508942.pdf (accessed 21 September 2016).

Lindberg, J. O., \& Olofsson, A. D. (Eds.) (2010). Online learning communities and teacher professional development: methods for improved education delivery. Hershey, Pennsylvania: IGI Global.

Lindberg, J. O., Olofsson, A. D., \& Fransson, G. (2017). Same but different? An examination of Swedish upper secondary school teachers' and students' views and use of ICT in education. The International Journal of Information and Learning Technology, 34(2), 1-12.

Livingstone, S. (2012). Critical reflections on the benefits of ICT in education. Oxford Review of Education, $38(1), 9-24$.

McGarr, O. (2009). The development of ICT across the curriculum in Irish schools: A historical perspective. British Journal of Educational Technology, 40(6), 1094-1108.

Miles, M. B., Huberman, A. M., \& Saldaña, J. (2014). Qualitative data analysis: A methods sourcebook. (3 ed.). Los Angeles: Sage. 
Mishra, P., \& Koehler, M. J. (2008). Introducing technological pedagogical content knowledge. Paper presented at the Annual Meeting of the American Educational Research Association New York City, March 24-28, 2008, p. 1-16.

OECD. (2001). Learning to change: ICT in schools. Paris: OECD Publishing.

OECD. (2015). Students, computers and learning: making the connection, PISA series. Paris: OECD Publishing.

Olofsson, A. D., Lindberg, J. O., \& Hauge, T-E. (2014). GCP5 multi-level evaluations of TEL. In F. Fischer, F. Wild, R. Sutherland \& L. Zirn (Eds.), Grand challenges in technology enhanced learning (pp. 12-15). London: Springer.

Olofsson, A. D., Lindberg, J. O., Fransson, G., \& Hauge, T-E. (2015). Uptake and use of digital technologies in primary and secondary schools - a thematic review of research. Nordic Journal of Digital Literacy, Jubileumsnummer (Special Issue) 2006-2016, 103-121.

Papert, S. (1997). Why school reform is impossible. The Journal of the Learning Sciences, 6(4), 417-427.

Penuel, W. R., Allen, A. R., Coburn, C. E., \& Farrell, C. (2015). Conceptualizing research-practice partnerships as joint work at boundaries. Journal of Education for Students Placed at Risk, 20(1-2), 182-197.

Phelps, R., Graham, A., \& Watts, T. (2011). Acknowledging the complexity and diversity of historical and cultural ICT professional learning practices in schools. Asia-Pacific Journal of Teacher Education, 39(1), 47-63.

Polly, D., Mims, C., Shepherd, C. E., \& Inan, F. (2010). Evidence of impact: Transforming teacher education with preparing tomorrow's teachers to teach with technology (PT3) grants. Teaching and Teacher Education, 26(4), 863-870.

Säljö, R. (2010). Digital tools and challenges to institutional traditions of learning: Technologies, social memory and the performative nature of learning. Journal of Computer Assisted Learning, 26(1), 53-64.

Schrum, L., \& Levin, B. B. (2013). Leadership for twenty-first-century schools and student achievement: Lessons learned from three exemplary cases. International Journal of Leadership in Education: Theory and Practice, 16(4), 379-398.

See, B. H., Gorard, S., \& Siddiqui, N. (2016). Teachers' use of research evidence in practice: A pilot study of feedback to enhance learning. Educational Research, 58(1), 56-72.

Shulman, L. S. (1986). Those who understand: Knowledge growth in teaching. Educational Researcher, $15(2), 4-14$

Shulman, L. (1987). Knowledge and teaching: Foundations of the new reform. Harvard Educational Review, $57(1), 1-22$.

Sipilä, K. (2014). Educational use of information and communications technology: Teachers' perspective. Technology, Pedagogy and Education, 23(2), 225-241.

Tay, L. Y., Lim, C. P., \& Lim, S. K. (2015). Differences in ICT usage across subject areas: A case of an elementary school in Singapore. Journal of Educational Computing Research, 53(1), 75-94.

Tondeur, J., Devos, G., Van Houtte, M., van Braak, J., \& Valcke, M. (2009). Understanding structural and cultural school characteristics in relation to educational change: The case of ICT integration. Educational Studies, 35(2), 223-235.

Tondeur, J., Forkosh-Baruch, A., Prestridge, S., Albion, P., \& Edirisinghe, S. (2016). Responding to challenges in teacher professional development for ICT integration in education. Educational Technology \& Society, 19(3), 110-120.

Voogt, J., Knezek, G., Cox, M., Knezek, D., \& ten Brummelhuis, A. (2011). Under which conditions does ICT have a positive effect on teaching and learning? A call to action. Journal of Computer Assisted Learning, 29(1), 4-14.

Voogt, J., Fisser, P., Pareja Roblin, N., Tondeur, J., \& van Braak, J. (2013). Technological pedagogical content knowledge - A review of the literature. Journal of Computer Assisted Learning, 29(2), 109-121.

Vrasidas, C. (2015). The rhetoric of reform and teachers' use of ICT. British Journal of Educational Technology, 46(2), 370-380.

Wang, S.-K., Hsu, H.-Y., Reeves, T. C., \& Coster, D. C. (2014). Professional development to enhance teachers' practices in using information and communication technologies (ICTs) as cognitive tools: Lessons learned from a design-based research study. Computers \& Education, 79, 101-115.

Ward, L., \& Parr, J. M. (2010). Revisiting and reframing use: Implications for the integration of ICT. Computers \& Education, 54(1), 113-122.

Wastiau, P., Blamire, R., Kearney, C., Quittre, V., Van de Gaer, E., \& Monseur, C. (2013). The use of ICT in education: A survey of schools in Europe. European Journal of Education, 48(1), 11-27.

Yeh, Y. F., Hsu, Y. S., Wu, H. K., Hwang, F. K., \& Lin, T. C. (2014). Developing and validating technological pedagogical content knowledge-practical (TPACK-practical) through the Delphi survey technique. British Journal of Educational Technology, 45(4), 707-722. 